\title{
Anguillicolosis: dynamics of the infection over two decades
}

\author{
F. S. Lefebvre ${ }^{1}$, A. J. Crivelli ${ }^{2, *}$ \\ ${ }^{1}$ Department of Zoology, University of Otago, PO Box 56, Dunedin, New Zealand \\ ${ }^{2}$ Station Biologique de la Tour du Valat, Le Sambuc, 13200 Arles, France
}

\begin{abstract}
The dynamics of the infection of the European eel Anguilla anguilla L. by the Asian nematode Anguillicola crassus Kuwahara, Niimi and Itagaki, 1974 (i.e. anguillicolosis) was monitored over 2 decades in an oligohaline canal in southern France (Camargue, Mediterranean coast). Since the first mention of the parasite in this canal in 1985, which was also the first record in France, prevalence of pre-adult and adult forms has risen from 32 to $73 \%$. However, during the last 7 yr (1997 to 2003), prevalence seems to have stabilized around values of 60 to $70 \%$ and parasite load, though inter-annual variation is substantial, shows no sign of increase (intensity for the last 5 yr: min. $=3.70$, max. $=9.66$, mean $=6.01$ ). Our results thus confirm the dynamic pattern observed elsewhere in Europe, i.e. a rapid spread following the introduction of the parasite in a water system and then stabilization around ceiling levels. We review possible mechanisms that may explain such a leveling off in the infection spread. We particularly document the possibility that repetitive infections may render the infected organ, i.e. the swimbladder, unsuitable for further A. crassus establishment. In support of this hypothesis, we showed that the infection rate is lower among eels with severely damaged swimbladders.
\end{abstract}

KEY WORDS: Epidemiology · Anguilla anguilla · Anguillicola crassus · Host-parasite system • Regulation process

Resale or republication not permitted without written consent of the publisher

\section{INTRODUCTION}

Anguillicolosis in European eels Anguilla anguilla (Linnaeus, 1758) and the American eel A. rostrata (Lesueur, 1817) is a real threat for aquaculture and is suspected of endangering eel populations in the wild (Moriarty \& Dekker 1997, Haro et al. 2000, Kirk 2003). The infection is caused by the exotic nematode $A n$ guillicola crassus Kuwahara, Niimi and Itagaki, 1974. This biological invader was originally endemic to East Asian countries, infecting the native Japanese eel $A$. japonica Temminck and Schlegel, 1846 (Egusa 1979, Nagasawa et al. 1994).

In the early 1980 s, the parasite was introduced into European waters, apparently from Japanese eels imported for consumption and for evaluation in aquaculture (Peters \& Hartmann 1986). In wild European eels, it was first observed in 1982 in Germany (Neu- mann 1985). Since then, Anguillicola crassus has spread with extraordinary rapidity (Kennedy \& Fitch 1990, Moravec 1992). It is currently recorded in nearly all European countries and in North Africa, in such a way that its distribution now approximately covers the geographic range of its new host (see Ashworth \& Blanc 1997, Rahhou et al. 2001, Kirk 2003).

In the 1990s, possibilities of transfer to the American eel Anguilla rostrata became apparent. The parasite was first observed in cultured American eels in Taiwan (Ooi et al. 1996) and then its presence was recorded in a wild eel from Winyah Bay, South Carolina (Fries et al. 1996). Subsequent sampling revealed that the nematode is now established as a permanent member in the fauna of several states of eastern North America: Florida, North Carolina, South Carolina, Maryland and New York (Barse \& Secor 1999, Barse et al. 2001, Moser et al. 2001). 
Although data on prevalence, abundance or parasite intensity are reported in nearly all affected countries, the dynamics of the infection still remains poorly documented, probably because of the lack of consistent sampling effort over a long period of time. From the few relevant studies hitherto available, it has been suggested that the infection spread might stabilize (Van Willingen \& Dekker 1989, Ashworth 1994, Molnár et al. 1994, Würtz et al. 1998, Lefebvre et al. 2002b), even though the nematode possesses many attributes of a successful invasive colonizer (Kennedy \& Fitch 1990).

Here, we present a long-term data set from a French survey program which monitored anguillicolosis over the 2 decades since its first detection in the Fumemorte canal in 1985 (Dupont \& Petter 1988). For the last 4 yr of study, we have also investigated the health state of the infected organ, i.e. the swimbladder. Possible mechanisms that may explain the observed trend in the dynamics of the infection are discussed in the light of the available knowledge concerning this recent host-parasite system.

\section{MATERIALS AND METHODS}

The survey area is the Fumemorte canal, a drainage canal within the Camargue (a wetland complex in the Rhône River delta, French Mediterranean coast). It collects rain and rice-field waters (pumped from the Rhône River), is over $17 \mathrm{~km}$ long and flows into coastal brackish lagoons. It is an oligohaline habitat with a muddy bottom and a mean depth of nearly $1 \mathrm{~m}$. More details concerning the physical parameters and fish communities of the canal can be found in Crivelli (1981).

From October 1982 to September 1983, eels in this canal were sampled monthly for an overall parasitological investigation (Dupont 1984). During this period, no Anguillicola crassus were found in the eel swimbladders $(\mathrm{n}=258)$. Two years later, in autumn 1985, specimens of $A$. crassus (pre-adult and adult forms) were detected in 8 eels collected in the canal $(\mathrm{n}=25$, prevalence $=32 \%)$. This constituted the first record of the parasite in France (Dupont \& Petter 1988).

In 1989 and 1990, and from 1997 to 2003, sampling was undertaken at the same fishing site, using the procedure described in Dupont (1984): a fyke net $(5 \mathrm{~mm}$ mesh) was set 1 wk per month and visited every morning. The total length of each eel caught was recorded to the nearest $1 \mathrm{~mm}$. The swimbladder was removed and macroscopically examined for the presence/ absence of pre-adult and adult forms (>2 mm long) of Anguillicola crassus. From 1997 to 2003, the number of lumen parasites was counted. For the last $4 \mathrm{yr}$ (from 2000 to 2003), the health state of the eel swimbladder was also assessed by using a Swimbladder Degenerative Index (SDI). The index ranges from 0 , when no pathological signs of infection were observed, to 6 , in cases of extremely damaged swimbladders (for more details, see Lefebvre et al. 2002a). Data on A. crassus numbers were computed for groups of eels with different SDI scores. In such cases, the terms prevalence and mean intensity (see Bush et al. 1997) were still used but referred specifically to infection rate and parasite load within each subsample of SDI scores.

For reasons of consistency, only infection data for autumn months (from September to December) are reported here. Note that no environmental parameters so far investigated have changed during the survey period (1982 to 2003), in particular: water salinity (annual mean value \pm SE [min.-max.]): $0.9 \pm 0.1 \mathrm{~g} \mathrm{l}^{-1}$ $(0.5-1.3)$; water temperature (annual mean value $\pm \mathrm{SE}$ [min.-max.]): $14.8 \pm 0.3^{\circ} \mathrm{C}(13.5-16.7)$.

\section{RESULTS}

There was a significant difference in eel size between years of study (Kruskal-Wallis ANOVA: $H_{8,673}$ $=36.44, \mathrm{p}<0.001$ ), but no particular trend could be detected across time (Spearman's rank test: $\mathrm{R}=0.18$, $\mathrm{n}=10, \mathrm{p}=0.63$ ). For this reason, the following epidemiological analyses were performed on observed parasite counts, not on data controlled for eel size.

The dynamics of the infection in the Fumemorte canal are presented in Table 1 and illustrated in Fig. 1.

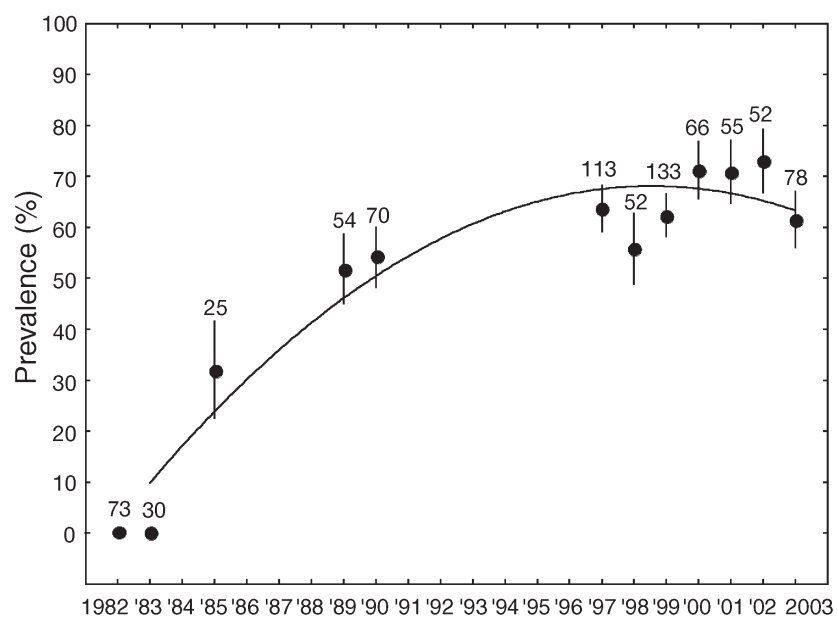

Fig. 1. Anguillicola crassus. Dynamics of the infection level (prevalence $\pm \mathrm{SE}$ ) over 2 decades since the first investigation in the Fumemorte canal. Sample sizes are indicated above dots. The first 2 points are derived from Dupont (1984). The third point is derived from Dupont \& Petter (1988) 
Table 1. Anguillicola crassus infecting Anguilla anguilla. Epidemiology of infection in the Fumemorte canal (south of France) between autumn 1982 and autumn 2003. The last column refers to the Swimbladder Degenerative Index (SDI), a way to assess damage caused by parasites in the infected organ. -: no data gathered

\begin{tabular}{|c|c|c|c|c|c|}
\hline Date & $\mathrm{n}$ & Eel size \pm SE $(\mathrm{mm})$ & Prevalence (\%) & Mean intensity $\pm \mathrm{SE}$ & $\mathrm{SDI} \pm \mathrm{SE}$ \\
\hline Jan 1982-Dec 1983 & 258 & 450 & 0 & - & - \\
\hline Sep-Dec 1985 & 25 & - & 32 & - & - \\
\hline Sep-Dec 1989 & 54 & $475.72 \pm 22.19$ & 51.85 & - & - \\
\hline Sep-Dec 1990 & 70 & $390.04 \pm 19.49$ & 54.29 & - & - \\
\hline Sep-Dec 1997 & 113 & $443.96 \pm 15.34$ & 63.72 & $5.49 \pm 0.91$ & - \\
\hline Sep-Dec 1998 & 52 & $420.52 \pm 22.61$ & 55.77 & $9.66 \pm 1.44$ & - \\
\hline Sep-Dec 1999 & 133 & $454.65 \pm 14.14$ & 62.41 & $7.22 \pm 0.85$ & - \\
\hline Sep-Dec 2000 & 66 & $513.45 \pm 20.07$ & 71.21 & $3.70 \pm 1.28$ & $1.60 \pm 0.13$ \\
\hline Sep-Dec 2001 & 55 & $424.95 \pm 21.98$ & 70.91 & $6.92 \pm 1.24$ & $2.65 \pm 0.14$ \\
\hline Sep-Dec 2002 & 52 & $431.23 \pm 22.61$ & 73.08 & $5.18 \pm 1.25$ & $2.52 \pm 0.15$ \\
\hline Sep-Dec 2003 & 78 & $510.58 \pm 18.46$ & 61.54 & $4.71 \pm 1.12$ & $2.40 \pm 0.12$ \\
\hline
\end{tabular}

The prevalence (\% of infected eels) rose from $32 \%$ in 1985 to nearly $50 \%$ in 1989 to 1990 , and then oscillated between $56 \%$ and $73 \%$ from 1997 to 2003. Data were best fitted by the polynomial equation: $y=2.07+$ $7.98 x-0.24 x^{2}\left(n=11, R^{2}=89 \%\right)$. From the curve shown in Fig. 1, it is apparent that the infection has reached a ceiling level of approximately 60 to $70 \%$ in less than a decade after the introduction of the parasite in the system.

For the last 7 yr of study (1997 to 2003), the parasite intensity showed large inter-annual variations (min. to max. annual values $\pm \mathrm{SE}: 3.70 \pm 1.28$ to $9.66 \pm 1.44$; Kruskal-Wallis ANOVA: $H_{6,356}=15.16, \mathrm{p}<0.05$, see Table 1, Fig. 2). Mean annual values did not increase through time and even showed a trend towards lower

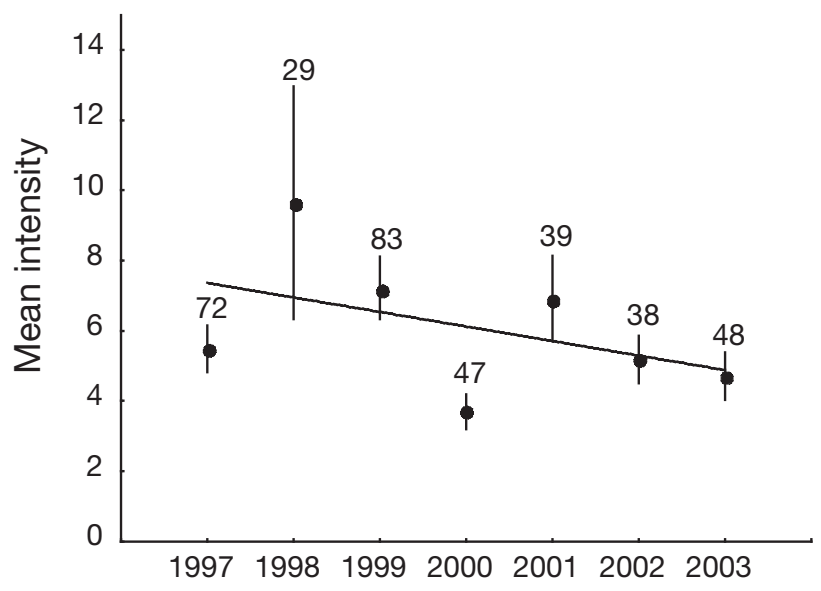

Fig. 2. Anguillicola crassus. Dynamics of the infection intensity (i.e. number of parasites per infected eel) during the last $7 \mathrm{yr}$ of study in the Fumemorte canal (mean autumn values \pm $\mathrm{SE})$. Sample sizes are indicated above dots parasite intensities in more recent years Spearman's rank test: $\mathrm{R}=-0.54, \mathrm{n}=7, \mathrm{p}=0.22$ ).

For the last 4 yr of study (2000 to 2003), the Swimbladder Degenerative Index showed significant variation in its mean value (min.-max. annual values $\pm \mathrm{SE}$ : $1.60 \pm 0.14$ to $2.65 \pm 0.14$; Kruskal-Wallis ANOVA: $\left.H_{3,246}=35.15, \mathrm{p}<0.001\right)$. There was a trend of increasing damage to the swimbladder through time but the correlation was not significant (Spearman's rank test: $\mathrm{R}=0.20, \mathrm{n}=4, \mathrm{p}=0.80$ ).

Prevalence in Anguillicola crassus worms varied between groups with different SDI scores (see Table 2, Kruskal-Wallis ANOVA: $\left.H_{6,246}=17.25, \mathrm{p}<0.01\right)$. When plotting prevalence values against SDI scores, a curvilinear relationship was generated (see Fig. 3). Data were best fit by the polynomial equation: $y=0.03+$ $0.42 x-0.06 x^{2}\left(n=7, R^{2}=98 \%\right)$. Regarding mean intensities, there was no significant difference between SDI scores (Kruskal-Wallis ANOVA: $H_{5,167}=4.82, \mathrm{p}=$ 0.44 ) and no function was able to satisfactorily describe the data (best fit for the polynomial equation: $y=-0.38$ $\left.+3.68 x-0.53 x^{2}, \mathrm{n}=6, \mathrm{R}^{2}=47 \%\right)$.

Table 2. Prevalence and mean intensity of Anguillicola crassus according to damage observed in the corresponding eel swimbladders. The number of eels used to compute these values is given in parentheses. SDI: Swimbladder Degenerative Index

\begin{tabular}{|lcc|}
\hline SDI score & Prevalence in \% (n) & Mean intensity \pm SE (n) \\
\hline 0 & $35.71(14)$ & $3.80 \pm 2.33(5)$ \\
1 & $68.42(38)$ & $3.58 \pm 1.02(26)$ \\
2 & $72.45(98)$ & $4.90 \pm 0.62(71)$ \\
3 & $75.76(66)$ & $5.88 \pm 0.74(50)$ \\
4 & $59.09(22)$ & $7.23 \pm 1.45(13)$ \\
5 & $28.57(7)$ & $1.00 \pm 3.68(2)$ \\
6 & $0(1)$ & - \\
\hline
\end{tabular}




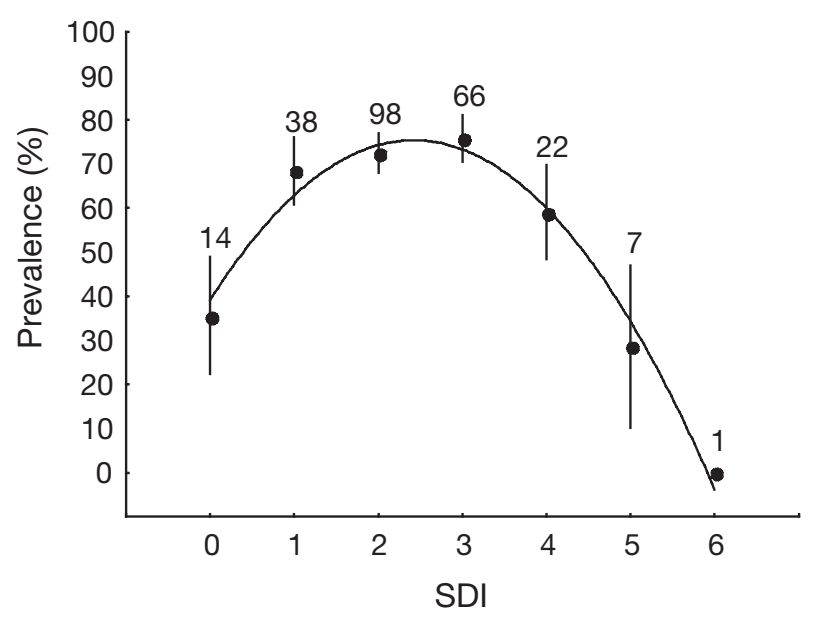

Fig. 3. Anguillicola crassus infecting Anguilla anguilla. Relationship between the severity of damage observed in the eel swimbladders (Swimbladder Degenerative Index, SDI scores) and the prevalence \pm SE among corresponding eels. Sample sizes are indicated above dots

\section{DISCUSSION}

This long-term survey of eels in the Fumemorte canal showed that the infection rate by the Asian nematode Anguillicola crassus rapidly spread in the first few years following its appearance, before stabilizing at a prevalence of around 60 to $70 \%$ in recent years. Data concerning parasite intensity, though highly variable from year to year, did not show any particular trends across time. From our data, it is thus obvious that the infection rate has reached a ceiling level. The possibility of a stabilization of the infection (in terms of prevalence and/or intensity) has already been suggested from studies in brackish lagoons of the same area (Lefebvre et al. 2002b) and also in other European countries (Netherlands: Van Willingen \& Dekker 1989; England: Ashworth 1994; Hungary: Molnár et al. 1994; Germany: Würtz et al. 1998).

Considering that no environmental parameters so far investigated have changed during our survey period (see 'Materials and methods'), it thus seems that constraints have operated in the host-parasite system. Referring to the available literature on this particular system, different mechanisms can be proposed to explain the observed stabilization of the infection: (1) Density-dependent regulation of larval populations of Anguillicola crassus within intermediate hosts. Ashworth et al. (1996) have effectively demonstrated that prevalence and mean intensity of $A$. crassus within copepods are density-dependent and approach an asymptote at increasing larval densities. Whatever the infection dose experienced, a proportion of uninfected copepods (from 20 to $60 \%$ according to the water tem- perature and copepod species) still remains. Such heterogeneity in the infection status of intermediate hosts may constrain or regulate the dynamics of the infection in the eel definitive host. (2) Density-dependent regulation of larval and adult $A$. crassus within the eel. Ashworth \& Kennedy (1999) have shown that the migration of larvae from the swimbladder wall into the swimbladder lumen appears to be inhibited by the presence of pre-established adult worms. These authors also pointed out a possible regulation of the number of female nematodes that mature through to the gravid state, with a constant mean number of gravid females of approximately 3 per infected host. So, within the eel host, A. crassus populations seem capable of constraining the numbers of larvae that establish to the adult stage, and the number of females that mature and reproduce. (3) Parasite-induced mortality of heavily infected eels. Such a mechanism, by removing a part of infected specimens from the host population, is expected to lower the observed prevalence values (Lester 1984). Cases of mortality due to the infection have been reported both in eel farms (Hartmann 1987, Liewes \& Schaminee-Main 1987) and in natural habitats (Molnár et al. 1991, Csaba et al. 1993, Baruš \& Moravec 1999). However, further investigations have highlighted the particular circumstances associated with these mass kills (presence of pyrethroid insecticide, high fish densities, exceptionally high temperatures, bacterial infections), in such a way that evidence for a generalized phenomenon operating in the wild is still lacking (Békési et al. 1997, Nemcsók et al. 1999). (4) Acquisition of host adaptations towards A. crassus. This may occur by cellular reaction (Haenen et al. 1989, Molnár 1994) or by immune reaction (Buchmann et al. 1991, Höglund \& Pilström 1995, Knopf et al. 2000). The role of host resistance and immune responses are still ambiguous in this host-parasite system. Clearly, the European eel is capable of mounting a humoral immune response against antigens of $A$. crassus (see for example Knopf et al. 2000) but its efficiency appears limited. The higher susceptibility of the European eel, in comparison to the native Japanese host eel (in terms of prevalence or histopathological damages, see Egusa 1979, Nagasawa et al. 1994) is thus assumed to result from a lower immune competence (Nielsen 1999). Typically, immuno-competence may only be acquired after long periods of parasite-host coevolution (Wakelin 1996), which is not the case here. However, the possibility of host adaptation in explaining the stabilization of the infection cannot be excluded. (5) Parasite-induced pathogenicity in the eel swimbladder. As a result of larval and adult activities (migration of L3 larvae through the swimbladder wall, blood feeding of worms on the capillary system of the swimbladder), infection 
causes important damage in the infected organ. Histopathological changes in the swimbladder structure have been reported extensively by many authors (Molnár et al. 1993, 1995 Haenen et al. 1994, Molnár 1994, Würtz \& Taraschewski 2000). Since these changes are thought to accumulate with host age (as suggested by the positive relationship between eel length and the severity of pathological signs, see Lefebvre et al. 2002b), multiple-infected swimbladders may become unsuitable habitats for $A$. crassus development. To some extent, this means that pathological changes, due to past or current infections, could prevent further re-infections.

Our recorded data concerning the health state of the swimbladder support this last hypothesis (see Fig. 3). After reaching a maximum level of almost $80 \%$ in moderately affected eels, prevalence then decreases among eels with severely damaged swimbladders. Such a feed-back process may impose a constraint on the spread of Anguillicola crassus and could explain the ceiling level observed in prevalence values.

To conclude, there is now increasing evidence that the spread of the swimbladder nematode Anguillicola crassus in the European eel Anguilla anguilla tends to stabilize within infected areas. However, as discussed above, it is not necessarily a desirable outcome since the observed stabilization in terms of prevalence and intensity values may simply reflect eel mortalities or accumulation of damages in the infected organ. This is all the more worrying since, at present, there is no known means of eradicating this pest. Even in aquaculture, no efficient prophylactic treatment (elimination of intermediate hosts) nor therapeutic treatment (anti-helmintics) against the nematode $A$. crassus have been demonstrated (Geets et al. 1992). Due to a similar life cycle, a similar geographic range and phylogenetic proximity (Aoyama et al. 2001), what is described for the European eel is also likely to happen to the American eel in the next few years.

Acknowledgements. The authors thank all the persons who contributed to the collection of data, namely P. Contournet, A. Acou, F. Dupont, F. Priour, O. Soulas and J. Panfili. We are also grateful to C. Kennedy and R. Poulin for their constructive comments on the manuscript.

\section{LITERATURE CITED}

Aoyama J, Nishida M, Tsukamoto K (2001) Molecular phylogeny and evolution of the freshwater eel, genus Anguilla. Mol Phylogenet Evol 20:450-459

Ashworth ST (1994) Possible regulation in the Anguillicola crassus host-parasite system. In: Pike AW, Lewis JW (eds) Parasitic diseases of fish. Samara Publishing, Tresaith, p 141-150

Ashworth ST, Blanc G (1997) Anguillicola crassus, un colonisateur agressif récemment introduit dans les stocks européens d'anguilles. Bull Fr Pêche Piscic 344/345:335-342
Ashworth ST, Kennedy CR (1999) Density-dependent effects on Anguillicola crassus (Nematoda) within its European eel definitive host. Parasitology 118: 289-296

Ashworth ST, Kennedy CR, Blanc G (1996) Density-dependent effects of Anguillicola crassus (Nematoda) within and on its copepod intermediate hosts. Parasitology 113:303-309

Barse AM, Secor DH (1999) An exotic nematode parasite of the American eel. Fisheries 24:6-10

Barse AM, McGuire SA, Vinores MA, Elerman LE, Weeder JA (2001) The swimbladder nematode Anguillicola crassus in American eels (Anguilla rostrata) from middle and upper regions of Chesapeake Bay. J Parasitol 87:1366-1370

Baruš V, Moravec F (1999) Anguillicolosis of the European eel (Anguilla anguilla) in the Czech Republic. Czech J Anim Sci 44:423-431

Békési L, Hornok S, Székely C (1997) Attempts to analyse Anguillicola crassus infection and the humoral host response in eels (Anguilla anguilla) of Lake Balaton, Hungary. Acta Vet Hung 45:439-445

Buchmann K, Pedersen LO, Glamann J (1991) Humoral immune response of European eel Anguilla anguilla to a major antigen in Anguillicola crassus (Nematoda). Dis Aquat Org 12:55-57

Bush AO, Lafferty KD, Lotz JM, Shostak AW (1997) Parasitology meets ecology on its own terms: Margolis et al. revisited. J Parasitol 83:575-583

Crivelli AJ (1981) Les peuplements de poissons de la Camargue. Rev Ecol 35:617-671

Csaba G, Láng M, Salyi G, Ramotsa J, Glávits R, Ratz F (1993) The nematode Anguillicola crassus (Nematoda, Anguillicolidae) and its role in the death of eels in Lake Balaton during 1991. Magy Allatorv Lapja 48:11-21

Dupont F (1984) Biologie des populations de Bothriocephalus claviceps cestode pseudo phyllidea parasite de l'anguille européenne. PhD thesis, University of Montpellier

Dupont F, Petter AJ (1988) Anguillicola, une épizootie plurispécifique en Europe: apparition de Anguillicola crassa (Nematoda, Anguillicolidae) chez l'anguille européenne Anguilla anguilla en Camargue, Sud de la France. Bull Fr Pêche Piscic 308:38-41

Egusa S (1979) Notes on the culture of the European eel $A$. anguilla in Japanese eel farming ponds. Rapp P-V Réun Cons Int Expl Mer 174:51-58

Fries LT, Williams DJ, Johnson SK (1996) Occurrence of Anguillicola crassus, an exotic parasitic swim bladder nematode of eels, in the southeastern United States. Trans Am Fish Soc 125:794-797

Geets A, Liewes EW, Ollevier F (1992) Efficacy of some anthelmintics against the swimbladder nematode Anguillicola crassus of eel Anguilla anguilla under saltwater conditions. Dis Aquat Org 13:123-128

Haenen OLM, Grisez L, De Charleroy D, Belpaire C, Ollevier F (1989) Experimentally induced infections of European eel Anguilla anguilla with Anguillicola crassus (Nematoda, Dracunculoidea) and subsequent migration of larvae. Dis Aquat Org 7:97-101

Haenen OLM, Van Banning P, Dekker W (1994) Infection of eel Anguilla anguilla (L.) and smelt Osmerus eperlanus (L.) with Anguillicola crassus (Nematoda, Dracunculoidea) in the Netherlands from 1986-1992. Aquaculture 126: 219-229

Haro A, Richkus W, Whalen K, Hoar A, Busch WD, Lary S, Brush T, Dixon D (2000) Population decline of the American eel: implications for research and management. Fisheries 28:7-16

Hartmann S (1987) Schwimblassenwürmer beim Aal. Fisch Teichwirt 38:2-3 
Höglund J, Pilström L (1995) Mechanical isolation and characterization of antigens from adult Anguillicola crassus. Fish Shellfish Immunol 5:51-60

Kennedy CR, Fitch DJ (1990) Colonization, larval survival and epidemiology of the nematode Anguillicola crassus, parasitic in the eel, Anguilla anguilla, in Britain. J Fish Biol 36: $117-131$

Kirk RS (2003) The impact of Anguillicola crassus on European eels. Fish Manag Ecol 10:385-394

Knopf KK, Naser MH, van der Heijden MH, Taraschewski H (2000) Humoral immune response of European eel Anguilla anguilla experimentally infected with Anguillicola crassus. Dis Aquat Org 42:61-69

Lefebvre F, Contournet P, Crivelli AJ (2002a) The health state of the eel swimbladder as a measure of parasite pressure by Anguillicola crassus. Parasitology 124:457-463

Lefebvre F, Contournet P, Priour F, Soulas O, Crivelli AJ (2002b) Spatial and temporal variation in Anguillicola crassus counts: results of a 4 year survey of eels in Mediterranean lagoons. Dis Aquat Org 50:181-188

Lester RJG (1984) A review of methods for estimating mortality due to parasites in wild fish populations. Helgol Meeresuners 37:53-64

Liewes EW, Schaminee-Main S (1987) Onderzoek aalparasiiet vordert. Aquacultuur 2:5-17

Molnár K (1994) Formation of parasitic nodules in the swimbladder and intestinal walls of the eel Anguilla anguilla due to infections with larval stages of Anguillicola crassus. Dis Aquat Org 20:163-170

Molnár K, Székely C, Baska F (1991) Mass mortality of eel in Lake Balaton due to Anguillicola crassus infection. Bull Eur Assoc Fish Pathol 11:211-212

Molnár K, Baska F, Csaba G, Glávits R, Székely C (1993) Pathological and histopathological studies of the swimbladder of eels Anguilla anguilla infected by Anguillicola crassus (Nematoda: Dracunculoidea). Dis Aquat Org 15:41-50

Molnár K, Székely C, Perényi M (1994) Dynamics of Anguillicola crassus (Nematoda: Dracunculoidea) infection in eels of Lake Balaton, Hungary. Folia Parasitol 41:193-202

Molnár K, Szakolczai J, Vetési F (1995) Histological changes in the swimbladder wall of eels due to abnormal location of adults and second stage larvae of Anguillicola crassus. Acta Vet Hung 43:125-137

Moravec F (1992) Spreading of the nematode Anguillicola crassus (Dracunculoidea) among eel populations in Europe. Folia Parasitol 39:247-248

Editorial responsibility: Wofgang Körting,

Hannover, Germany
Moriarty C, Dekker W (1997) Management of the European eel: second report of the EC concerted action AIR A941939. Fish Bull 15:1-110

Moser ML, Patrick WS, Crutchfield Jr JU (2001) Infection of American eels, Anguilla rostrata, by an introduced nematode parasite, Anguillicola crassus, in North Carolina. Copeia 3:848-853

Nagasawa K, Kim YG, Hirose H (1994) Anguillicola crassus and Anguillicola globiceps (Nematoda: Dracunculoidea) parasitic in the swimbladder of eels (Anguilla japonica and A. anguilla) in East Asia: a review. Folia Parasitol 41:127-137

Nemcsók J, Bálint T, Fazakas J, Kátai F and 7 others (1999) The contribution of a pyrethroid insecticide to the massive eel (Anguilla anguilla) devastation, in Lake Balaton, in 1995. Acta Biol Hung 50:161-173

Neumann W (1985) Schwimmblasenparasit Anguillicola bei Aalen. Fisch Teichwirt 36:322

Nielsen ME (1999) An enhanced humoral immune response against the swimbladder nematode, Anguillicola crassus, in the Japanese eel, Anguilla japonica, compared with the European eel, Anguilla anguilla. J Helminthol 73: $227-232$

Ooi H-K, Wang W-S, Chang H-Y, Wu C-H, Lin C-C, Hsieh M$\mathrm{T}$ (1996) An epizootic of anguillicolosis in cultured American eels in Taiwan. J Aquat Anim Health 8:163-166

Peters G, Hartmann F (1986) Anguillicola, a parasitic nematode of the swimbladder spreading among eel populations in Europe. Dis Aquat Org 1:229-230

Rahhou I, Melhaoui M, Lecomte-Finiger R, Morand S, Chergui $H$ (2001) Abundance and distribution of Anguillicola crassus (Nematoda) in eels Anguilla anguilla from Moulouya Estuary (Morocco). Helminthologia 38:93-97

Van Willingen J, Dekker W (1989) 1988 update on Anguillicola in Dutch outdoors waters. In: EIFAC Working Party on Eel, Porto, Portugal, 29 May to 3 June, 1989, p 1-8

Wakelin D (1996) The immune response. In: Wakelin D (ed) Immunity to parasites. Cambridge University Press, Cambridge, p 11-35

Würtz J, Taraschewski H (2000) Histopathological changes in the swimbladder wall of the European eel Anguilla anguilla due to infections with Anguillicola crassus. Dis Aquat Org 39:121-134

Würtz J, Knopf K, Taraschewski H (1998) Distribution and prevalence of Anguillicola crassus (Nematoda) in eels Anguilla anguilla of the rivers Rhine and Naab, Germany. Dis Aquat Org 32:137-143

Submitted: March 22, 2004; Accepted: September 6, 2004

Proofs received from author(s): November 15, 2004 